\title{
Age Related Structural Changes in the Bulbourethral Gland of Gaddi Goat (Capra hircus)
}

\author{
Cambios Estructurales Relacionados con la Edad en la \\ Glándula Bulbouretral de la Cabra Gaddi (Capra hircus)
}

Archana P.; R. S. Katiyar; D. N. Sharma; M. M. Farooqui \& Ajay Prakash

ARCHANA, P.; KATIYAR, R. S.; SHARMA, D. N.; FAROOQUI, M. M. \& PRAKASH, A. Age related structural changes in the bulbourethral gland of Gaddi goat (Capra hircus). Int. J. Morphol., 29(2):591-597, 2011.

SUMMARY: A study was conducted on the bulbourethral glands of 30 Gaddi goats, divided into three groups of 10 animals in each viz; Prepubertal ( 1 day old to $<18$ months of age), Pubertal ( 18 months to $<5 y$ rs of age) and Postpubertal ( $>5 y$ rs of age). The study revealed that the glands grew at a faster speed up-to 6 months of postnatal life after which the pace slowed down considerably. Almost 10 times increase in weight and more than three times increase in all the linear mensurations were observed in prepubertal group from the time of birth. The stroma vs parenchyma ratio which was 80:20 in one-day-old kids showed three times increase in parenchyma in prepubertal animals, and the ratio became 43:57. In one day old kids luminated and non-luminated secretory end pieces were arranged in small groups around widely luminated duct; the forerunner of the central cistern. Initially the gland contained serous as well mucous end pieces; the latter being more preponderant. But in pubertal animals it became a mucous type gland, with only a little numbers of serous end pieces. Histochemically, the glandular acini were reactive to PAS and Alcian blue indicated the presence of glycol-muco-complex in the secretory components of gland.

KEY WORDS: Bulbourethral gland; Gaddi goat; Histology; Histochemistry.

\section{INTRODUCTION}

Gaddi goats are the migratory goats generally reared in the mountainous temperate zone of (1500-3000 meters MSL) of North-Western Himalayan region of India. These are the main source of livelihood of the tribes dwelling in these areas. They are dual purpose animals and are good for meat, milk, hair and hide etc.

The bulbourethral glands are the accessory sex gland, located dorso-lateral to the penile portion of the urethra, at the root of the penis (Eurell \& Frappier, 2007). It adds fluids to the semen during the process of ejaculation, which acts as the lubricant and make the semen less watery to provide a suitable living environment for the sperm. Certain anatomical, histological and histochemical studies have been conducted on the bulbourethral gland of goat (Kundu, 1980; Yao \& Eaton, 1954; Gupta \& Singh, 1982; Pawar et al., 1986; Pyne et al., 1991). But a composite study on the structural changes with age has not been available; therefore the present work has been conducted on the bulbourethral gland of Gaddi goats from one day old to more than five years of age, to record a sequential account of the structural changes in the development of bulbourethral gland.

\section{MATERIAL AND METHOD}

Complete male genitalia were dissected out from 30 male Gaddi goats divided into three groups of 10 animals in each viz; Prepubertal (1 day old (new born) to $<18$ months of age), Pubertal (18 months to < 5yrs of age) and Postpubertal ( $>5 \mathrm{yrs}$ of age). After detailed gross morphological examinations, the gross biometrical parameters of bulbourethral gland were measured with the help of Vernier Calipers and non-stretchable nylon thread and recorded separately for each animal.

Deen Dayal Upadhyaya Veterinary University-Mathura, India. 
Thin pieces of tissue samples were collected from each bulbourethral gland and fixed in the $10 \%$ neutral buffered formalin, formal acetic alcohol (FAA) and cold acetone. The fixed tissues were processed through the routine alcohol-benzene schedule, infiltrated and embedded in paraffin (60-62 $\mathrm{C}$ melting point). The cold acetone fixed tissues were embedded in paraffin of low $\left(52-54^{\circ} \mathrm{C}\right)$ melting point for carbohydrate and enzymes study. Thin paraffin sections $(5 \mu)$ were cut and stained with Haematoxylin and Eosin (Luna, 1968) for routine fibrocellular architecture, Van Gieson's stain (Luna, 1968) for collagen, Gomori's reticulin method (Luna, 1968) for reticular fibers and Weigert's resorcin-fuchsin and Orcein stains (Luna) for elastic fibers, PAS with and without saliva as well as diastase (Davenport, 1960) for polysaccharides and glycogen, Alcian blue at $\mathrm{pH}$ 2.5 (Luna) for acid mucopolsaccharides (AMPS), Azodye method for alkaline and acid phosphatase (Barka \& Anderson, 1963), Sudan Black-B in propylene glycol (Luna) for lipids, Bromphenol- blue method (Pearse, 1968) for protein and Feulgen reaction (Davenport) for DNA demonstration. Micrometrical measurements were recorded with the help of calibrated ocular micrometer. Data were subjected to standard statistical analysis (Snedecor \& Cochran, 1994).

\section{RESULTS}

The bulbourethral glands in Gaddi goats were paired, rounded or ovoid in shape, located on either side of the pelvic urethra close to the ischial arch. Each gland was covered by a distinct fibrous capsule which was ensheathed by the thick bundles of striated bulbocavernosus muscle.

In newborn kids, average weight of bulbourethral gland measured $0.09 \mathrm{~g}(0.09-0.10 \mathrm{~g})$. The average length, width, and thickness were $0.68 \mathrm{~cm}(0.63-0.69 \mathrm{~cm}), 0.54 \mathrm{~cm}$ $(0.52-0.57 \mathrm{~cm})$ and $0.45 \mathrm{~cm}(0.38-0.53 \mathrm{~cm})$ respectively. A significant increase in the various parameters took place in the first six months of postnatal life. At six months of the age the glands weighed $1.60 \mathrm{gm}(1.58-1.63 \mathrm{~g})$. The average length, width and thickness measured $1.50 \mathrm{~cm}(1.49-1.51 \mathrm{~cm})$,
$1.50 \mathrm{~cm}(1.49-1.50 \mathrm{~cm})$ and $0.90 \mathrm{~cm}(0.82-1.08 \mathrm{~cm})$ respectively. The average weight, length, width and thickness of bulbourethral glands in prepubertal, pubertal and postpubertal animals are summarized in Table I.

\section{Histology}

Capsule: Each bulbourethral gland was enclosed in true capsule, which measured $78.40 \pm 0.2 \mu$ in thickness in newborn kids. It gave off $45.08 \mu$ thick interlobular connective tissue septae which divided the gland into lobes and lobules of different sizes (Fig. 1). The capsule was rich in collagen, but the interlobular and intralobular connective tissue had mild concentration of collagen fiber. Only very fine elastic fibers were visible in the capsule. The overlying loose connective tissue contained fibroblasts, blood vessels, nerves (Fig. 2) and occasionally autonomic ganglion.

In pre-pubertal, Gaddi goats, the capsule had circularly arranged collagenous bundles, abundant reticular and few elastic fibers. The elastic fibers were frequently observed in the walls of the blood vessels and very fine elastic fibers were noticed in the connective tissue trabeculae. With the increase in age, the connective tissue stroma vs parenchyma ratio decreased. The percent ratio of connective tissue and parenchyma was 80:20 in one-day-old kids, which became $43: 57$ in late pre-pubertal animals (12 months of age).

The thickness of capsule increased with age in pubertal and further in post-pubertal animals (Table II). The collagen and reticular fibers of capsule became coarser. The amount of elastic fibers also increased with age. The thickness of interlobular and intralobular connective tissue decreased and consequently the parenchyma of the gland increased with age.

Secretory end pieces: The bulbourethral gland of Gaddi goat was compound tubuloalveolar type (Fig. 1). In newborn kids the solid and luminated secretory end pieces were arranged in small groups around the widely luminated ducts (Fig. 3). The average diameter of solid secretory end pieces was $36.43 \mu$ in one-day-old kids, which became $47.57 \mu$ in

Table I. Morphological parameters (Mean \pm S.E) of bulbourethral gland in Gaddi goats in various age groups. $\mathrm{n}=10$.

\begin{tabular}{lccc}
\hline Parameter & Pre-Pubertal & Pubertal & Post-Pubertal \\
\hline Weight $(\mathrm{g})$ & $0.93 \mathrm{a} \pm 0.09(0.09-1.63)$ & $1.57^{\mathrm{b}}{ }^{\mathrm{a}} 0.17(0.75-2.86)$ & $2.06^{\mathrm{b} \pm} 0.17(0.78-2.91)$ \\
Length $(\mathrm{cm})$ & $1.15 \mathrm{a} \pm 0.07(0.63-1.68)$ & $1.32^{\mathrm{a}}{ }^{ \pm} 0.03(1.10-1.60)$ & $1.73^{\mathrm{b} \pm} 0.07(1.20-2.10)$ \\
Width $(\mathrm{cm})$ & $1.09 \mathrm{a} \pm 0.07(0.52-1.74)$ & $1.22 \mathrm{a} \pm 0.03(0.9-1.50)$ & $1.62^{\mathrm{b} \pm} 0.07(1.24-2.24)$ \\
Thickness $(\mathrm{cm})$ & $0.78 \mathrm{a} \pm 0.03(0.38-1.08)$ & $1.14^{\mathrm{b} \pm} \pm .03(0.80-1.40)$ & $1.32^{\mathrm{b} \pm} \pm 0.08(0.87-1.90)$ \\
\hline
\end{tabular}

Figures in the parenthesis show the significant difference between the groups. 
Table II. Micrometrical parameters of the various components of bulbourethral gland in Gaddi goats at various age groups.

\begin{tabular}{lccc}
\hline Parameters & Pre-pubertal & Pubertal & Post-pubertal \\
\hline Thickness of capsule & $92.12 \mathrm{a} \pm 4.00$ & $125.73 \mathrm{~b} \pm 2.05$ & $154.93^{\mathrm{c} \pm} 4.35$ \\
& $(78.4-11.27)$ & $(114.66-134.26)$ & $(134.26-174.44)$ \\
Thickness of interlobular tissue & $35.51 \mathrm{c} \pm 2.00$ & $22.70 \mathrm{~b} \pm 0.85$ & $12.71 \mathrm{a} \pm 0.65$ \\
& $(26.95-45.08)$ & $(19.29-27.01)$ & $(2.95-5.45)$ \\
Thickness of intralobular connective tissue & $13.85 \mathrm{c} \pm 0.73$ & $7.81 \mathrm{~b} \pm 0.61$ & $4.15 \mathrm{a} \pm 0.29$ \\
& $(10.67-17.93)$ & $(5.22-10.89)$ & $(70.82-80.59)$ \\
Secretory end pieces & & & \\
Diameter of luminated acini & $51.69 \mathrm{a} \pm 2.90$ & $68.32 \mathrm{~b} \pm 0.84$ & $75.45 \mathrm{c} \pm 1.02$ \\
& $(38.47-62.87)$ & $(59.93-71.05)$ & $(70.82-80.59)$ \\
Diameter of non-luminated acini & $47.57 \mathrm{a} \pm 2.74$ & $64.08 \mathrm{~b} \pm 1.07$ & $66.89 \mathrm{~b} \pm 0.72$ \\
& $(36.43-59.47)$ & $(59.93-71.05)$ & $(62.87-70.82)$ \\
Epithelial height & $18.16 \mathrm{a} \pm 0.71$ & $24.02 \mathrm{~b} \pm 0.57$ & $27.51 \mathrm{c} \pm 0.30$ \\
& $(14.76-21.57)$ & $(21.34-27.24)$ & $(25.99-29.16)$ \\
Duct & & & $54.48 \mathrm{c} \pm 0.66$ \\
Diameter of duct & $37.06 \mathrm{a} \pm 0.87$ & $46.10 \mathrm{~b} \pm 0.77$ & $(51.18-57.20)$ \\
& $(32.92-41.76)$ & $(42.44-49.59)$ & $26.40 \mathrm{c} \pm 0.49$ \\
Epithelial height & $14.36 \mathrm{a} \pm 0.51$ & $21.09 \mathrm{~b} \pm 0.67$ & $(23.72-27.80)$ \\
\hline
\end{tabular}

Values are in $\mu \mathrm{m}$ (mean \pm S.E) are the means of ten means of ten animals. Figures in the parenthesis indicate the range shows the significant difference between the groups.

late prepubertal animals. The respective parameter of luminated end pieces was $38.47 \mu$ in one-day-old kids and $51.68 \mu$ in late prepubertal animals. Mucous as well as serous secretory alveoli were present in the bulbourethral gland; however, the number of mucous alveoli was more than the serous alveoli. The typical mucous acini were lined with simple columnar epithelium with distinct cell membrane. The cytoplasm was clear with basally placed nuclei. The darkly stained nuclei of these cells varied from spherical,

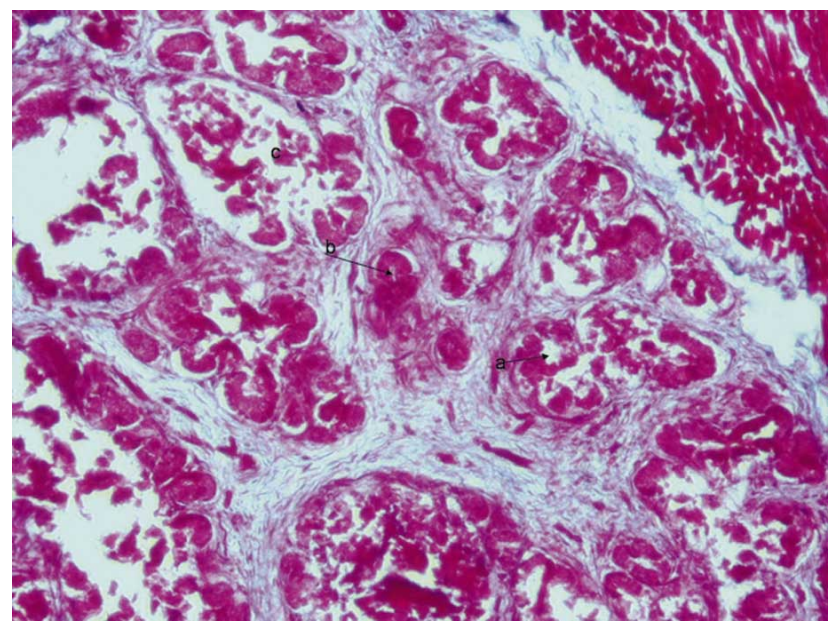

Fig. 1. Photomicrograph of bulbourethral gland of one day old Gaddi kid showing typical compound tubuloacinar type of gland showing luminated (a) and non- luminated (b) acini, central cistern (c) surrounded by collagen tissue. Masson's trichrome stain X 100. oval to flattened in shape and contained distinct nucleolus. The height and width of the lining epithelium of luminated secretory end pieces in new born kids measured $14.75 \mu$ and $5.33 \mu$ respectively. The same parameters of non- luminated end pieces were $15.89 \mu$ and $4.19 \mu$, respectively. The respective parameters in the pre-pubertal animals measured $18.16 \mu, 4.76 \mu$ and $14.50,4.50 \mu$ (Table II). The nuclei of both the type of end pieces were round, oval, angular or flat in shape.

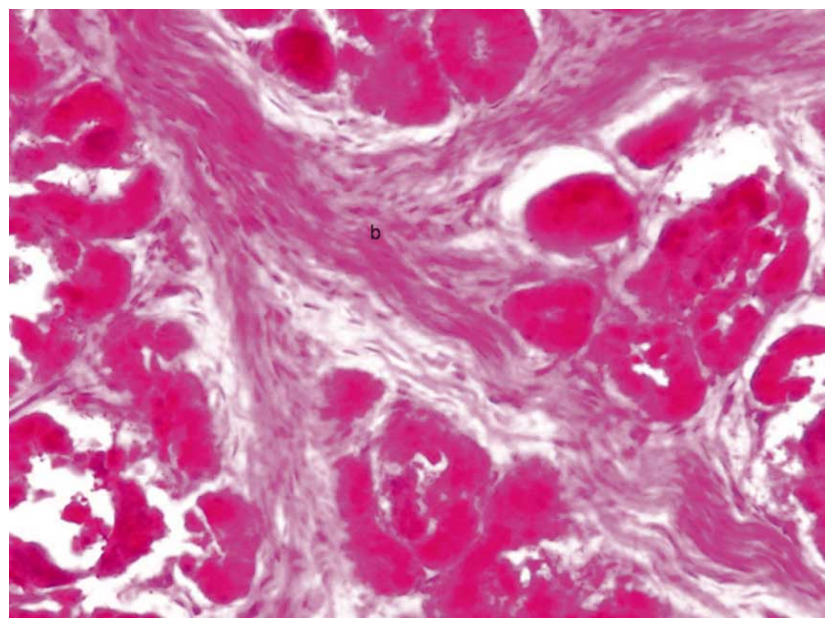

Fig. 2. Photomicrograph of bulbourethral gland of one-day-old Gaddi kid showing nerve bundles traversing through the glandular parenchyma (a). PAS X 100 


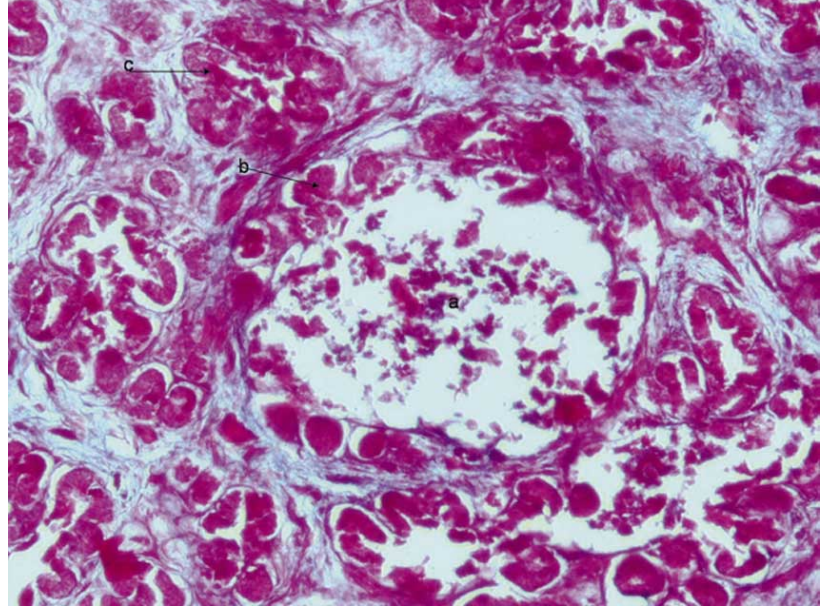

Fig. 3. Photomicrograph of bulbourethral gland of one-day-old Gaddi kid showing a large cistern (a) surrounded by the ducts (b) and acini (c) of different sizes and shapes. Masson's trichrome stain X 100.

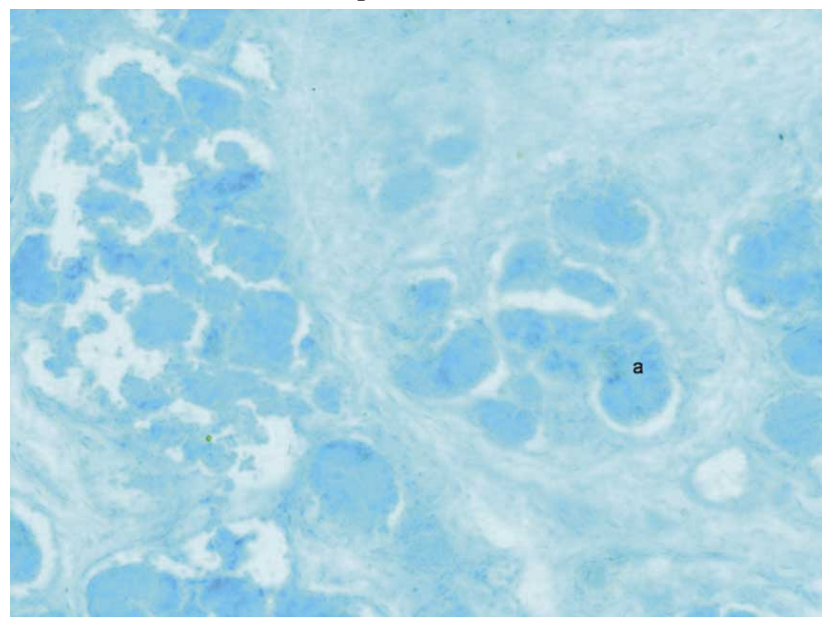

Fig. 4. Photomicrograph of bulbourethral gland of one-day-old Gaddi kid showingstrong AMPS reaction in all secretory end pieces (acini) (a). Alcian Blue X 100

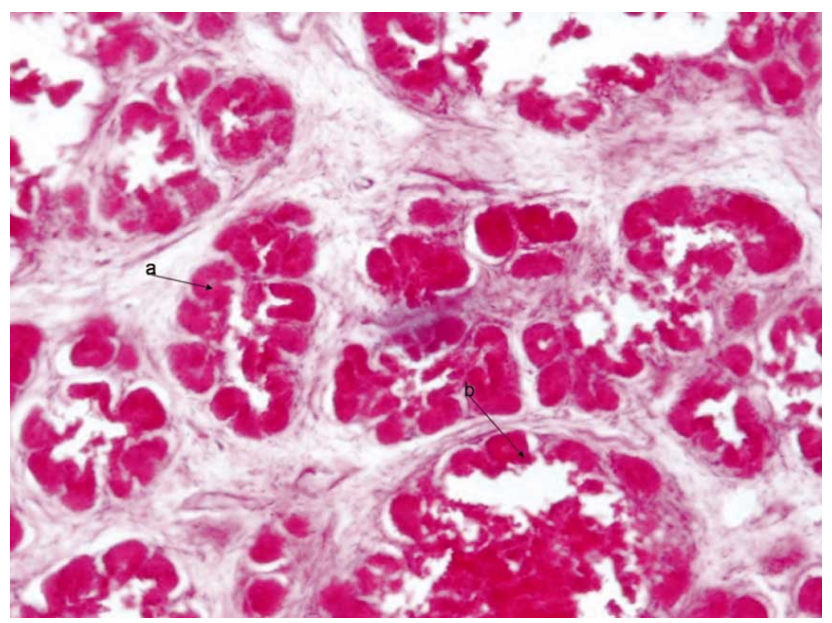

Fig. 5. Photomicrograph of bulbourethral gland of one-day-old Gaddi kid showing PAS positive reaction in epithelial cells of the acini (a) and ducts (b). PAS X 100
With the advancement of age, the glands became highly lobulated in pubertal animals and further in postpubertal animals. The number of luminated end pieces increased in pubertal animals as compared to preceding age group, however, both type of secretory end pieces were observed in pubertal as well as in post-pubertal animals. These were dominantly mucous in nature. The diameter of luminated as well as non-luminated acini increased with age (Table II). The glands were lined with simple columnar epithelium and the height of lining cells increased significantly in pubertal animals and post-pubertal animals.

Duct. In new born kids, the ducts were very few and short (Fig. 3). They were seen originating as an out pocket of cisterns. Their diameter measured $32.92 \mu$. These were lined with simple cuboidal to low columnar epithelium. The diameter of duct increased with increase in age (Table II).

Histochemistry. In just born kids, the interlobular connective tissue was mildly PAS positive and the smooth muscle fibers of interlobular septae were moderately reactive. The basement membrane showed a saliva resistant PAS positive reaction of a very strong intensity. Very strong AMPS reaction for mucopolysaccherides was observed in almost all acini (Fig. 4). However, the cytoplasm of the epithelial cells lining the cisterns, ducts and mucous alveoli was filled with saliva resistant PAS positive material. The secretory material in the lumina of the mucous alveoli was PAS positive (Fig. 5). Basement membrane and epithelial cells stained weakly with Sudan black-B for lipids. The intensity of alkaline phosphate was mild to moderate in the basement membrane and moderate in the epithelial cells. It also reacted weakly to acid phosphatase. Mild to moderate Feulgen reaction was observed in the nuclei of the glandular cells (Fig. 6) and in the stromal cells. The cytoplasm of the acinar cells showed moderate to intense activity of Bromophenol-Blue for protein.

In pubertal animals, except a mild reaction for alkaline phosphatase the various histochemical moieties such as carbohydrate, fats and acid phosphatase could not be observed in the capsule and stroma of the bulbourethral gland. The cytoplasm of epithelial cells lining the mucous acini showed strong PAS reaction (Fig.7) and alcianophilic material of very strong concentration. Fat was not traceable in the luminal secretion but was observed in the lining cells of acini. Intense Acid phosphatase and alkaline phosphatase (Fig. 8) reaction were observed in the parenchymatous elements. Moderate to strong Bromophenol-Blue reaction was noticed in the acini.

In postpubertal Gaddi goats, the histochemical reactions were similar to those recorded in the glands of pubertal animals. 


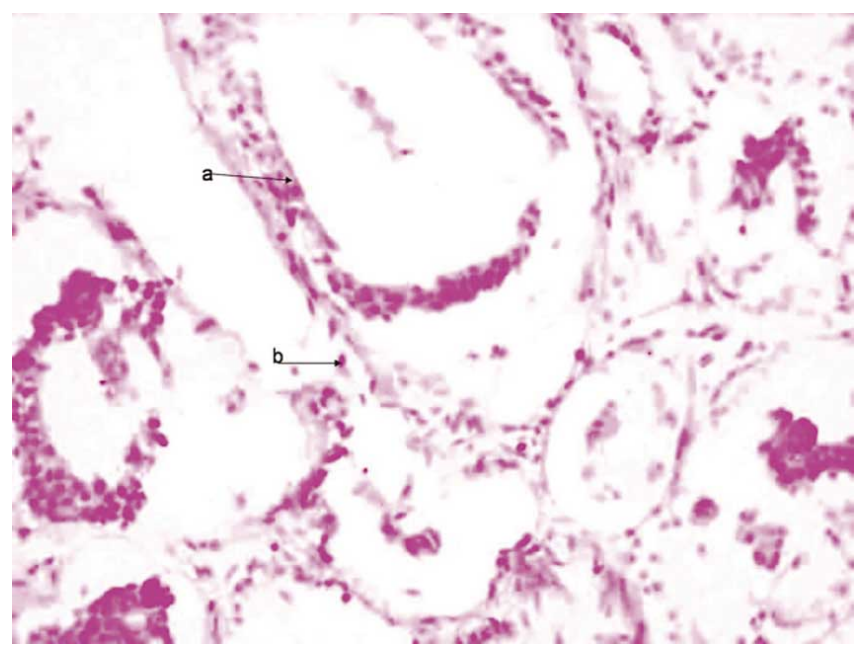

Fig. 6. Photomicrograph of bulbourethral gland of one-day-old Gaddi kid showing presence of DNA in the nuclei of glandular cells (a) and in the stromal cells (b). Feulgens reactionX100

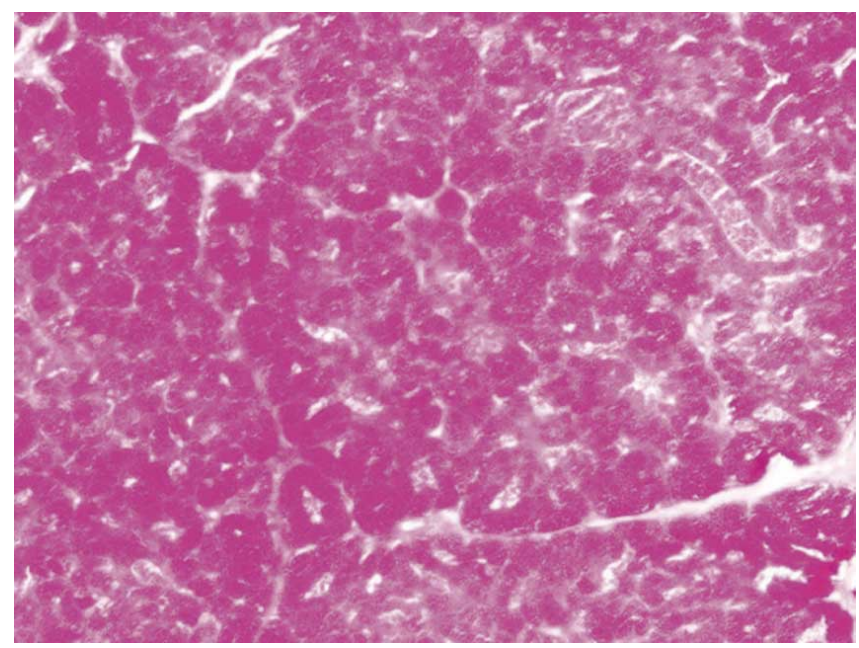

Fig. 7. Photomicrograph of bulbourethral gland of pubertal Gaddi goat showing intense PAS reaction in the acini. PAS X 100

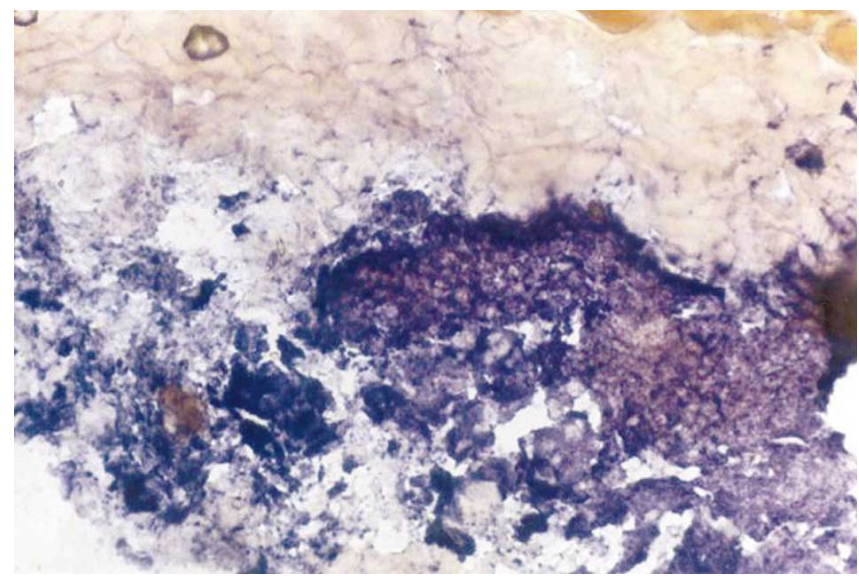

Fig. 8. Photomicrograph of bulbourethral gland of pubertal Gaddi goat showing intense alkaline phosphatase reaction in the epithelial lining of acini. Azodye methodX200

\section{DISCUSSION}

The paired rounded encapsulated bulbourethral glands were located on either side of the urethra at the ischial arch covered by the bulbocavernosus muscle in goat as also in buffalo (Chandrapal, 1976; Sudhakar, 1982) and other domestic animals (Eurell \& Frappier). It weighed $0.09 \mathrm{~g}$ and measured $0.68 \times 0.54 \times 0.45 \mathrm{~cm}$ in one-day-old kids. Kundu did not find a cover of bulbospongiosus muscle on these glands in goat. The gland grew at a faster speed up-to 6 months of postnatal life after which the pace slowed down considerably. The overall mean weight in prepubertal animals was $0.93 \mathrm{~g}$ and the average measurements were $1.15 \times 1.09 \times 0.78 \mathrm{~cm}$. The two glands of either side being almost symmetrical in all measurements. Almost 10 times increase in weight and more than three times $(300 \%)$ increase in all the linear mensurations were observed in prepubertal group from the time of birth (Table I). When the growth of the gland in the postpubertal animals was compared with that in the pubertal animals, all the parameters on an average grew to more than $30 \%$ over their previous record. This indicated a much slower speed of growth in postpubertal animals than in the early prepubertal animals. Gupta recorded a continuous growth of gland with age but with a faster pace during the first 12 months of postnatal life in Beetal goats. Stallcup (1969) correlated the weight of bovine testes with the weight of bulbourethral gland positively up-to 12 months of age, after which there was no correlation between the two parameters, howevere, Kundu did not find any correlation between different measurements of the gland and their age in goats.

The stroma vs parenchyma ratio in one day old kids was 80:20 which finally averaged 43:57 in prepubertal animals confirming there at least a 3 times (300\%) growth in the parenchyma during this period. The parenchyma grew further during the period of puberty making this ratio to $23: 77$. The growth of parenchyma became almost static beyond the age of puberty. In postpubertal animals this ratio became 20:80. This indicated a final 4 times (400\%) increment in the parenchyma of the gland at the expense of the stroma which showed 4 times decrease in the stroma in the postpubertal animals. This confirms the findings of Singh (1967), Chandrapal and Sudhakar on continous growth of the parenchyma with age in buffalo.

The growth curve on the capsular thickness showed a continous curvilinear growth pattern with age. The interlobular and intralobular connective tissue components however, reduced considerably with age (Table II). Kundu described a fibroelastic nature of the capsule, whereas the 
interlobular septae comprised of irregular connective tissue with few muscle fibers.

The gland was a typical tubuloalveolar type as described by Eurell \& Frapper (2007), predominantly mucous in nature. The alveoli were lined by tall columnar epithelium, as also reported by Yao \& Eaton, Wrobel (1970), Kundu and Gupta \& Singh and Gupta in goats and in other domestic animals. Yao \& Eaton found no histological difference in the histology of pre and postnatal gland except in the size and relative amount of the glandular tissue which also confirms the present observations. The data also revealed a progressive increase in the diameter of luminated and nonluminated secretory end pieces and also the epithelial height of the secretory components (Table II). Similar observations were recorded in terms of ducts and height of the lining epithelia, from prepubertal to pubertal and then in the postpubertal animals gland.

The histochemical observations revealed strongly PAS reactive cytoplasmic granules in the ductal epithelium and lining cells of the secretory end pieces (Fig. 5). The reaction was completely labile with the diastase treatment. In later periods (pubertal and postpubertal) the intensity of PAS staining reduced although slightly to moderate, indicating a complex nature of glycogen (glycol-complex) in these animals. Reaction for AMPS with Alcian Blue was also found in similar locations. This further extended the possibility of existence of certain glycol-muco-complex in them. The reaction being more in the secretory components than in the conducting segments of the parenchyma relates its source of creation into the secretory cells and transport through the duct system. Pyne et al. and Pawar et al. also localized the acid and neutral mucopolysaccharides along with the glycogen in the glandular and ductular epithelia of ram. Saikairi et al. (2004) while studying the glycolconjugates complex of the vesicular gland stated that these neutral and acidic glyco-conjugates with various saccherides residues must be involved in various fertilization events. The same appears to hold true to these secretions of the bulbourethral gland which are added to the semen as the last contribution from the male sex organs before being finally discharged into the female genitalia. The epithelial cells and the basement membrane demonstrated mild to moderate degree of sudanophilia in Gaddi goats and the reaction intensified in the pubertal and postpubertal animals. Gupta recorded the increased intensity of lipid coloration in the acinar cells at 12 month age. Chandrapal, Pawar et al., Pyne et al. and Sudhakar also reported the increased intensity of lipid reaction with the maturation of the animals. These results are compatible with the present observations indicating their correlation with the maturity of animals i.e. testicular hormonal circulation in the blood.

Reaction for protein and DNA was of moderate to intense degree in the acinar cells and tubular cells of bulbourethral glands of Gaddi goats of all ages (Fig. 6). Pyne et al. recorded mild to intense reaction for protein and DNA in the glandular epithelium of Chota Nagpuri goats. The reactions are indicative of high protein turnover and cellular response in the glands for the manufacture and secretion of seminal plasma components of these goats. The distribution of alkaline and acid phosphatase enzymes in various components of the glands at various ages were similar to those described in the bulls (Rollinson 1954; Stallcup), buffalo (Chandrapal), goat (Gupta \& Singh; Gupta; Pyne et $a l$.) and ram (Pawar et al.). These reactions were more intense in glandular secretory cells than in the tubular cells. Alkaline phosphatase reaction was also more concentrated along the basement membrane, endothelium of blood vessels and nuclear membrane. The acid phosphatase reaction appeared as more granular in the supranuclear cytoplasm of acinar cells and their nuclear membrane. These enzymes are highly active in the functionally active glandular cells of bulbourethral gland and thus are responsible for the maintenance of their normal secretory function.

ARCHANA, P.; KATIYAR, R. S.; SHARMA, D. N.; FAROOQUI, M. M. \& PRAKASH, A. Cambios estructurales relacionados con la edad en la glándula bulbouretral de la cabra Gaddi (Capra hircus). Int. J. Morphol., 29(2):591-597, 2011.

RESUMEN: Se realizó un estudio sobre las glándulas bulbouretrales de 30 cabras Gaddi, divididas en tres grupos de 10 animales cada uno; prepúberes (desde 1 día de edad hasta $<18$ meses), púberes (desde 18 meses hasta $<5$ años de edad) y postpuberales ( $>5$ años de edad). El estudio reveló que las glándulas crecen a una mayor velocidad hasta los 6 meses de vida postnatal, después de lo cual el ritmo baja considerablemente. En el grupo prepuberal se observó un aumento casi 10 veces en peso y más de tres veces en todas las mediciones lineales. La relación estroma v/s parénquima fue de 80:20 el primer día postnacimiento, mostrando un aumento de tres veces en el parénquima en los animales prepúberes, llegando a una proporción 43:57. En una de las cabras de un día de edad las piezas terminales secretoras luminal y no-luminal se organizaron en pequeños grupos alrededor del conducto luminal; el precursor de la cisterna central. Inicialmente la glándula contenía piezas terminales serosas y mucosas. Esta última tenía una mayor preponderancia. Sin embargo, en animales puberales se convirtió en una glándula de tipo mucosa, con sólo un pequeño número de piezas terminales serosas. Histoquímicamente, los acinos glandulares reactivos al PAS y azul Alcian indicaron la presencia de glicol-muco-complejos en los componentes de secreción de la glándula.

PALABRAS CLAVE: Glándulas bulbouretrales; Cabra Gaddi; Histología; Histoquímica. 


\section{REFERENCES}

Barka, T. \& Anderson, P. J. Histochemistry: Theory, Practice and Bibliography. New York, Harper and Row Publisher Inc., 1963.

Chandrapal. Gross histological and histochemical studies on the male genital system of buffalo (Bubalus bubalis). Ph.D. Thesis. Agra University, Agra, 1976.

Davenport, H. A. Histological and histochemical technics. Philadelphia, W. B. Saunders Company, 1960.

Eurell, J. A. \& Frappier, B. L. Textbook of Veterinary histology. Ames, Blackwell publishing, 2007.

Gupta, A. N. Correlative Anatomy of the testes, epididymis \& accessory sex glands in goat. Ph. D. Thesis, HAU, Hisar, 1989.

Gupta, A. N. \& Singh, Y. Histological and histochemical studies on the bulbourethral glands of normal and castrated goats. Indian J. Anim. Sci., 52:758-63, 1982.

Kundu, P. B. Anatomical studies on the accessory male sex glands (gross and microscopic) of the Indian goat (Jamunapari and cross Jamunapari). Indian J. Anim. Health, 19:151-3,1980.

Luna, L. G. Manual of Histological staining methods of the armed Forces Institute of pathology. $3^{\text {rd }}$ ed. New York, McGraw-Hill, 1968.

Pawar, H. S.; Roy, K. S. \& Saigal, R. P. Histochemical localization of carbohydrates, lipids and enzymes in bulbourethral gland of ram. Indian J. Anim. Sci., 56:1879, 1986.

Pearse, A. G. E. Histochemistry Theoretical and Applied. London, Churchill, 1968.

Pyne, S. K.; Sinha, R. D. \& Chauhan, H. V. S. Histochemical study on the bulbourethral gland of normal and vasectomised goats (Capra hircus). Indian Vet. J., 68:145-7, 1991.

Rollinson, D. L. H. A study of the distribution of acid and alkaline phosphatase in the genital tract of the Zebu bull (Bos indicus). J. Agric. Sci., 45:173-8, 1954.

Sakairi, A.; Tsukise, A.; Habata, I.; Nara, T. \& Meyer, W. Glycoconjugate histochemistry of the seminal vesicles of the Japanese miniature (Shiba) goat. J. Vet. Med. A Physiol. Pathol. Clin. Med., 51(2):39-45, 2004.

Singh, R. N. Histological and histochemical studies on the accessory reproductive gland of male Indian Buffalo. M. V. ScThesis, Magadh University, Gaya, 1967.

Snedecor, G. W. \& Cochran, W. G. Statistical Methods. $8^{\text {th }}$ edn. Ames, Iowa State University Press, 1994.

Stallcup, O. T. Enzymatic activity of bovine accessory glands. J. Anim Sci., 28:145, 1969.

Sudhakar, L. S. Histological and histochemical changes in the male accessory genital glands of Murrah buffalo during postnatal development. Ph.D. Thesis. Haryana Agricultural University, Hisar, 1982.

Wrobel, K. H. Untersuchungen Zur Feinstruktur und Histochemie der Glandula bulbourethralis der Ziege. Z. Zellforsch, 108:582-96, 1970.

Yao, T. S. \& Eaton, O. N. Postnatal growth and histological development of the reproductive organs in male goats. Am. J. Anat., 95(3):401-31, 1954.

\section{Correspondence to:}

Dr. Archana Pathak

Associate Professor

Department of Anatomy

COVSc. \& A.H.

Pt. Deen Dayal Upadhyaya Veterinary University-Mathura INDIA

Phone: +91- 9458030888

Email: pathak_arcvik@yahoo.com

Received: 22-11-2010

Accepted: 24-02-2011 